Copyright (C) 2021 by Cherkas Global University

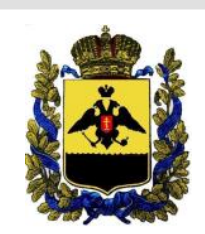

Published in the USA

Bylye Gody

Has been issued since 2006.

E-ISSN: $2310-0028$

2021. 16(4): 1849-1856

DOI: $10.13187 /$ bg.2021.4.1849

Journal homepage:

https://bg.cherkasgu.press

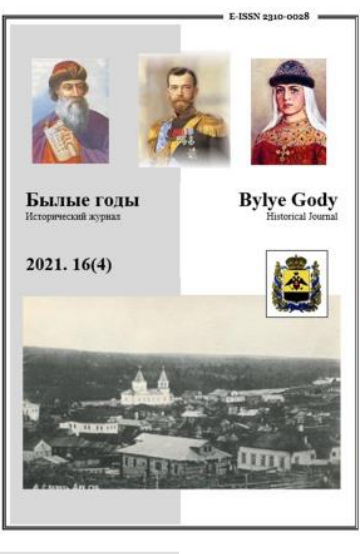

\title{
Text Analysis of the Yenisei Provincial Administrations and the Yenisei Provincial Court documents about officials 'abuse in Siberia in the second half of the 19th century
}

\author{
Tatyana G. Karchaeva a , *, Alexander G. Gryaznukhin a, Galina M. Lushchayeva a, Oleg G. Alekseev a \\ a Siberian Federal University, Russian Federation
}

\begin{abstract}
This article tested the facts of the abuse of office by local government officials in Siberia. The article talks about the officials of the Yenisei province, who committed malfeasance in the second half of the 19th century. The source base of the study is documents from 1860 to 1890 s. These are documents of the Yenisei Provincial Court and the Yenisei General Provincial Administration. These historical sources are kept in funds No. 141 and No. 545 of the State Archives of the Krasnoyarsk Territory (Krasnoyarsk). Content analysis of the text of archival documents is the main research method. We obtained the results of the study by analyzing administrative and statistical documents, form lists (personal files of officials). These documents contain hidden and explicit information. Content analysis makes it possible to establish the facts of crimes of local officials of the Yenisei province. The most common crimes are the theft of papers, things from public places, violation of seals, abuse of power, illegal actions of officials in the storage and management of property entrusted to them in the service, forgery at work, injustice, bribes. Punishment for these crimes was carried out according to the norms from the fifth section "On crimes and misdemeanors in the service of the state and public" of the Code of Criminal and Correctional Punishments of 1866. Surveys of the Yenisei province and official statistics indicate a small number of malfeasance - only $1.4-2.5 \%$ among others in the province. The biographical data of specific officials cited in the article paint an average portrait of a local civil servant of the district and provincial levels of government brought to justice. However, on the example of one of the criminal cases of the 1860 s it has been proven that not all officials were responsible. It was the murder of the treasurer of the Yenisei provincial government and the theft of a sum of 8,085 rubles. 88 1/4 kopeck High-ranking officials in Siberia could avoid punishment for malfeasance in the Russian Empire.
\end{abstract}

Keywords: officialdom, civil servants, bribery, official crimes, abuse of office, content analysis, provincial court, general provincial administration, Yenisei province, Siberia, Russian Empire.

\section{1. Введение}

Вторая половина XIX в. в истории Российской империи - сложный и противоречивый этап, но достаточно хорошо представленный в материалах фондов государственных и муниципальных архивов. В исторической науке доказано, что документы официального делопроизводства органов государственной власти всегда несут в себе явную и скрытую информацию (Ковальченко, 2003: 132-137). Метод формализованного анализа текста уже на протяжении более полувека рассматривается как один из способов повышения информационной отдачи исторического источника. Контент-анализ, приобретший популярность в последнее время у историков, позволяет комбинировать качественные и количественные подходы в анализе текста исторического документа, извлекать из всего разнообразия имеющейся в нем информации специально интересующие

\footnotetext{
${ }^{*}$ Corresponding author

E-mail addresses: tatyana-verkhoturova@yandex.ru (T.G. Karchaeva) 
исследователя вопросы. Одной из тем рассмотрения в подобной форме архивных документов официального делопроизводства может стать история чиновничества.

Цель статьи - установить факты должностных злоупотреблений местных государственных служащих в Енисейской губернии во второй половине XIX в., используя контент-анализ как метод исследования.

Территориальные рамки работы определены в границах Енисейской губернии - крупнейшей административно-территориальной единицы Восточной Сибири, «простиравшейся до 2259562,3 квадратных верст или 46 699,82 квадратных миль», уступавшей по площади в Российской империи только Якутской области (ГАКК. Ф. 31. Оп. 1. Д. 5О. Л. 5, 13, 14, 20).

\section{2. Материалы и методы}

Источниковая база исследования представлена документами официального делопроизводства Енисейского губернского суда и Енисейского общего губернского управления (далее также - ЕОГУ), хранящимися в одноименных фондах № 141 и № 545 Государственного архива Красноярского края (Красноярск, Российская Федерация).

Подвергшиеся контент-анализу документы Енисейского губернского суда позволили увидеть подробное содержание дел, участниками которых были местные чиновники (ГАКК. Ф. 141. Оп. 1. Д. 659. Л. 1-297).

Распорядительные, статистические документы и документы по личному составу ЕОГУ дали возможность установить посредством контент-анализа закономерности в деятельности данного главного учреждения губернского уровня власти в процессе выявления и внутреннего расследования должностных преступлений:

«Дело ЕОГУ по обвинению чиновников в незаконных действиях по службе за 1889 г.», содержащее справки о чиновниках, привлекаемых к ответственности за упущения по службе (ГАКК. Ф. 595. Оп. 1. Д. 3162);

«Дело ЕОГУ по обвинению коллежского регистратора Поротова в должностном преступлении за 1891-1892 гг.», включающем в себя выписки из журнала Енисейского губернского совета, относящиеся к вопросам, рассмотренным в деле, а также рапорт Ачинского полицейского окружного управления с подробным описанием совершенного преступления (ГАКК. Ф. 595. Оп. 1. Д. 3680);

«Дело ЕОГУ об аресте чиновников Енисейской губернии за разные проступки, 1892 г.» (ГАКК. Ф. 595. Оп. 1. Д. 4217).

Среди документов статистического и оперативного учета и отчетности рассмотрены «Обзоры Енисейской губернии за 1882 и 1883 г., хранящиеся в фонде №31 «Енисейский губернский статистический комитет» (ГАКК. Ф. 31. Оп. 1. Д. 41, 50), а также “Статистические сведения для составления отчета за 1893 г.» (ГАКК. Ф. 31. Оп. 1. Д. 162. Т. 1). Данного вида внешняя и внутренняя документация содержит «ведомости о числе и роде преступлений» по Енисейской губернии и ее округам за указанные годы.

Самостоятельное значение для исследования данной темы имеют документы по личному составу - формулярные списки (аттестаты) и личные дела чиновников (ГАКК. Ф. 595. ОП. 45. Д. 116. Л. 5-7; ГАКК. Ф. 595. ОП. 45. Д. 68. Л. 10б.-2). Они содержат биографические данные и информацию об имевшихся случаях незаконных действий по службе, что позволяет представить портрет среднестатистического чиновника местного органа власти Енисейской губернии 1870-1890-х гг., совершившего противозаконные действия по должности.

Методологическая основа работы предполагает использование общенаучных методов познания (анализ, синтез, сравнение) и специально-исторических (проблемно-хронологический, ретроспективный). Определяющим методом информационного анализа текстов архивных документов был выбран контент-анализ. Использование данного метода работы с историческими источниками позволило извлечь из всего разнообразия сведений необходимые данные, характеризующие положение дел с наличием должностных преступлений местных чиновников Енисейской губернии во второй половине XIX в.

\section{3. Обсуждение}

История чиновничества как предмет исследования представляет интерес для многих историков современности (Gentes, 2003; Bloch, 2005; Друзяка, Дударенок, 2018; Чуб, 2018; Плех, 2019; Degtyarev et. al., 2020). В последние годы появилось много научных работ, в содержании которых присутствует информация о деятельности местных органов государственной власти в Сибири и непосредственно их служащих, занимавших важные должности (Дамешек, Дамешек, 2019; Жулаева и др., 2019; Карчаева, 2019; Матханова, 2020; Anisimova et al., 2018; Vititneva et al., 2020; Gryaznukhin et al., 2020; Karchaeva et al., 2018; Karchaeva et al., 2019). Наличие должностных преступлений и проступков в работе органов государственной власти на местном уровне - актуальный вопрос для научного сообщества и широкой общественности (Дамешек, Дамешек, 2020: 103-107; Молнева, 2008; Писарькова, 2002; Dyatlov, Dyatlova, 2020: 624; Malyutina et al., 2019: 1430; Lyubichankovskiy, 2020: 728-230). Деятельность правительственных структур по борьбе с упущениями по службе на примере Енисейской губернии в

$$
-1850-
$$


дореволюционный период российской истории может быть рассмотрена для проведения исторических параллелей с современностью.

\section{4. Результаты}

\section{1. Статистика совершенных незаконных действий по службе}

Либеральные реформы Александра II, так сильно изменившие российское общество после 1860-х гг., в Сибири введены не были. Сибирское чиновничество, реализовавшее идеи центральной власти на местах, представляло собой совсем «узкий» слой общества, отделенный от основного населения высоким сословным положением, уровнем культуры и образования, более высоким доходом, возможностью иметь досуг и отдых. Разумеется, привилегированное положение государственных служащих и понимание ими своего «важного» положения вызывало случаи должностных злоупотреблений.

Анализ статистических данных по Енисейской губернии за 1880-1890-е гг. показал, что наиболее распространенными правонарушениями местных чиновников по государственной и общественной службе были действия или бездействия, описанные в пятом разделе «О преступлениях и проступках по службе государственной и общественной» Уложения о наказаниях уголовных и исправительных 1866 г.

В «Обзорах Енисейской губернии» за 1882, 1883 гг. (раздел «Народная нравственность»), а также в числе статистических сведений, собранных для составления всеподданнейшего отчета губернатора Енисейской губернии в Министерство внутренних дел за 1893 г., присутствуют данные о числе осужденных по сословиям и количестве преступлений и проступков, совершенных «по службе государственной и общественной» (ГАКК. Ф. 31. Оп. 1. Д. 5О. Л. 26-29; Д. 162. Т. 1. Л. 30 об.-31). Как известно, в Сибири существовали послабления в доступе на государственную службу и выходцы из непривилегированных сословий присутствовали на должностях среднего и низшего рангов (Карчаева, 2017: 242, 248).

Так, в 1881 г. в Енисейской губернии были установлены факты совершения 962 преступлений, по которым были осуждены 2049 чел., в 1882 г. выявлено 1026 преступлений, осуждено по ним 1914 чел. Доля преступлений и проступков по государственной и гражданской службе была совсем невелика: в 1881 г. - 24 преступления (2,5\%), в 1882 г. - 13 преступлений (1,4\%). В совершении неправомерных действий по государственной и общественной службе в 1881 г. судебные наказания с записью в формулярный список получили 37 чел. (дворяне - 20 чел., крестьяне - 16 чел., мещане 1 чел.), за 1882 г. подобных статистических сведений в отчете не представлено (ГАКК. Ф. 31. Оп. 1. Д. 50. Л. 26-27, 43 об.-44). В 1893 г. ведомость о числе и роде преступлений по округам Енисейской губернии свидетельствует о восьми раскрытых случаях нарушения закона в Красноярском округе, среди них четыре - это растрата казенных средств, один - оскорбление, три - потеря служебных бумаг (ГАКК. Ф. 31. ОП. 1. Д. 162. Т. 1. Л. 30 об.-31). Процент преступлений чиновников по государственной и общественной службе был все-таки совсем небольшим пропорционально населению губернии. Так, жителей всех сословий в Енисейской губернии, по данным на 1 января 1882 г., было 421010 душ обоего пола, в 1883 г. - 424347 (в сравнении с минувшим годом больше на 3337 чел.), по данным на 1 января 1884 г., - 429592 души обоего пола (больше на 5245 чел.) (ГАКК. Ф. 31. Оп. 1. Д. 5О. Л. 13-14, 20).

\section{2. Осужденные чиновники за совершенные упущения по службе}

Анализ формулярных списков и официальных документов Енисейского общего губернского управления дал общее представление о должностных лицах, понесших официальное наказание. Например, в 1889 г. выявлено 14 чел., из которых 8 были служащими полиции:

- секретарь Ачинской полиции Лясота и столоначальник того же управления Осипов, преданные суду (Енисейскому губернскому суду) по делу об утрате переписки о незаконной продаже крестьянином Субачевым товаров, то есть по обвинению в таком преступном действии, как «принятие должностным лицом денег или вещей от имени сельского общества», предусмотренном ст. 411 («...важные упущения от нерадения или медленности»);

- земский заседатель первого участка Енисейского округа Кузнецов, осужденный решением Енисейского губернского суда по ст. 411 («...важные упущения от нерадения или медленности») и по п. 6 ст. 416 («...за не высылку с первой почтой из присутственного места дел и бумаг, следующие к немедленному отправлению»);

- бывший помощник Енисейского полицейского пристава Васильев, понесший наказание по ч. 3 ст. 354 (присвоение или растрата казенного имущества и государственных доходов);

- чиновник особых поручений Енисейского общего губернского управления надворный советник Анатолий Иванович Васильев - ст. 343 (превышение власти или беззаконное бездействие) и ст. 404 (слабый надзор за подчиненными, нарушение в делах и порядке службы);

- полицейский надзиратель города Канска фон-Францен - ст. 338 (превышение власти и самовольное решение дела), ст. 348 (взятие под стражу без соблюдения на то правил), ст. 356 (промедление в отправке денежных сумм); 
- канский полицейский надзиратель Кузнецов - нанесение побоев крестьянину Филиппу Коробченко, наказание по ст. 343 (превышение власти или беззаконное бездействие);

- бывший полицейский пристав города Красноярска Знаменский - за утрату подложного векселя;

- бывший полицейский пристав города Красноярска Ложников - ст. 338 (превышение власти и самовольное решение дела), ст. 341 (превышение власти или беззаконное бездействие с отстранением от должности, службы);

- помощник горного инспектора Покрассо - за нанесение оскорбления действием казаку Дронину (ст. 400 «Уложения о наказаниях...»);

- статский советник Баршевский - за допущение разного рода злоупотреблений при несении обязанностей Туруханского отдельного пристава;

- Ачинский окружной исправник Смирнов, Ачинский полицейский надзиратель Шабанов, секретарь Ачинской полиции Баранович - ст. 370 (несправедливое решение в гражданском или уголовном деле), ст. 371 (недостаточный надзор за правильностью и законностью судебных решений) (ГАКК. Ф. 595. ОП. 1. Д. 3162. Л. 2-19).

Архивные материалы характеризуют перечисленных чиновников, обвиненных в незаконных действиях по службе, как должностных лиц, ревностных по службе, но имевших сложные отношения с коллегами.

Среднестатистическим и наиболее интересным примером, подтверждающим вышесказанное суждение, служит биография коллежского асессора Иосифа Ивановича Лясоты, 1832 года рождения, православного, происходившего по сословной принадлежности из не утвержденных герольдией дворян (сын чиновника Нижнеудинского окружного управления Иркутской губернии) (ГАКК. Ф. 595. Оп. 1. Д. 209. Л. 15).

Документы из его личного дела свидетельствуют, что секретарь Ачинской полиции шел к должности достаточно долго, был требовательным по отношению к государству, так как из-под его пера уходило много обращений (заявлений, записок) в адрес вышестоящих инстанций, предметом которых были просьбы предоставления права на бесплатное обучение в гимназии его дочери, на собственную досрочную пенсию, получение просроченного следующего классного чина, изменение формулировок записей в его формулярном списке.

И.И. Лясота воспитывался в частном пансионе и впоследствии окончил полный курс Нижнеудинского уездного училища, был женат первым браком, имел одну дочь 1860 года рождения. Государственную гражданскую службу он начал в 1848 г., то есть в 16 лет, с должности канцеляриста второго разряда в Ананьевском уездном суде, через год был утвержден в должности журналиста, затем надсмотрщика крепостных дел, а с 1852 г. «по просьбе и с разрешения Генерал-губернатора Восточной Сибири Адъютанта Графа Муравьева-Амурского» был переведен в Енисейскую губернию исполняющим должность письмоводителя в Канскую полицейскую управу, а через 20 лет, то есть в 1872 г., по собственному желанию был причислен к Енисейскому общему губернскому управлению, не раз командировался исполнять должности (временно замещать) окружных исправников, заседателей в Енисейском, Ачинском и Минусинском округах (ГАКК. Ф. 545. ОП. 1. Д. 209. Л. 15-36).

Возникавшие вопросы о сроках службы, по которым И.И. Лясота писал записки в вышестоящие инстанции, чтобы «добиться справедливости, могли возникнуть у чиновника в связи с его увольнениями из гражданской службы в 1875, 1877 гг. «по домашним обстоятельствам» и последующими поступлениями его на службу в Томскую губернию и обратно в Енисейскую. В собственноручно заполненных И.И. Лясотой записках приведены расчеты его служебного стажа по годам, месяцам и дням, присутствуют написанные красным карандашом формулировки «не знаю, почему так?» и фраза «Почему единовременная выдача пенсии и по 9.07.1879 г., а не к производству таковой впредь до назначения мне жалованья, превышающего размер пенсии? - вопрос Господину Енисейскому гражданскому губернатору / отдельным членам совета Главного управления Восточной Сибири...» (ГАКК. Ф. 545. ОП. 1. Д. 209. Л. 40, 42, 64).

Иосиф Иванович Лясота во время службы заседателем первого участка Мариинского округа Томской губернии в 1877 г. получил благодарность от лица Томского губернатора за раскрытие злоупотреблений со стороны волостных голов и писарей. Однако, вернувшись в Красноярск, уже в ноябре 1877 г. по решению Енисейского губернского суда он, находясь на должности заседателя первого участка Ачинского округа, получил официальный выговор (с внесением в VII графу формулярного списка) за превышение власти по делу о наказании розгами отставного мастерового Гороблагодатских заводов Осипа Черняева. После этого случая он был отстранен от должности, причислен к Енисейскому общему губернскому управлению, но по истечении четырех месяцев срока ожидания и возможного последовавшего назначения, уволен в отставку с 31.05.1879 г. (ГАКК. Ф. 545. Оп. 1. Д. 209. Л. 39 об.-40).

Анализ его личного дела показал, что отставной чиновник с данным решением не был согласен и в записке Красноярскому городскому полицейскому управлению требовал изменить в своем аттестате (формулярном списке) формулировку «уволен в отставку по истечении 4-х месяцев» на фразу «уволен в отставку по прошению», иначе он грозился «принести от куда следует жалобу», так 
как принял за личное оскорбление факт того, что для него не нашлось за четыре месяца никакой должности. Он считал себя невиновным и писал объяснение (рис.).

Несмотря на то, что я трудился изо всех сил, чтобы оправдать Ваше доверие при назначении меня в село Покровское, я все-таки лишился места, не знаю за что. Не имея возможности оправдаться, потому что из понятной робости не могу лично объясниться, как бы того желал, я решил обратиться к вашему Превосходительству с моей убедительной просьбой дать мне классную должность. Вы хорошо знаете, что чиновнику без должности есть нечего, и без дела меня скука одолевает.

...Попади я на службу не к Франку, я бы и теперь служил. Но Франк такой человек, с которым я не имел и не могу иметь ничего общего.

Скажу прямо: он не любит Вас и не заботился о Вашей славе. Теперь, вероятно, и Вы сами убедитесь, что Франк во всем Вас обманывал.

$Я$ не сделал ничего бесчестного или преступного, всегда стремился исполнить Вашу волю по чистой совести. С народом я был ласков, всегда доступен и справедлив.

Рис. 1. Записка Красноярскому городскому полицейскому управлению от коллежского асессора И.И. Лясоты о несправедливости наказания, 1879 г.

Источник: ГАКК. Ф. 595. ОП. 1. Д. 209. Л. 2-14.

Иосиф Иванович Лясота после проступка 1877 г. был вновь принят на службу в Енисейскую казенную палату (ГАКК. Ф. 595. Оп. 1. Д. 209. Л. 44). И, как свидетельствуют документы Енисейского общего губернского управления, через 10 лет был снова предан суду по делу об утрате переписки о незаконной продаже товаров, находясь на должности секретаря полиции Ачинского округа Енисейской губернии (ГАКК. Ф. 595. Оп. 1. Д. 3162. Л. 1).

Формулярные списки других чиновников, в которых были найдены записи о совершенных ими противозаконных действиях по государственной и общественной службе, свидетельствуют о том, что за все проступки по должности наказание определялось Енисейским губернским судом, но не всегда попадало в общую статистику, например указанную в Обзорах Енисейской губернии.

Подобными примерами могут служить формулярные списки далее указанных чиновников 1870-1890-х гг.:

- коллежский советник Владимир Павлович Калинин - Енисейский окружной исправник, хорошо образованный (окончил Императорский Казанский университет со званием действительного студента и чином XII класса), имевший орден Святого Александра 3-й степени за участие в Крымской войне 1853-1856 гг., женатый вторым браком и имевший троих детей (старший сын находился на должности секретаря Енисейского губернского правления), в возрасте 45 лет (в 1877 г.) получивший выговор по делу о розыгрыше его женой лотереи без разрешения Правительства (ГАКК. Ф. 595. ОП. 45. Д. 116. Л. 5);

- канцелярский служитель Андрей Матвеевич Постников - 53-летний журналист Минусинского окружного полицейского управления, происходивший из прощенных поселенцев, получивший выговор за медлительность выполнения служебных поручений (ГАКК. Ф. 595. Оп. 45. Д. 69. Л. 1 об.-2).

4.3. Чиновники, уклонившиеся от наказания за упущения и противозаконные действия по службе

Анализ архивных документов показал, что некоторые чиновники не получали должного наказания за совершенные преступления и проступки. Ярким примером может служить рассматриваемое в совете Главного управления Восточной Сибири (Иркутск), Енисейском губернском суде (Красноярск) и Правительствующем сенате (Санкт-Петербург) в течение 21 года (с 1866 по 1887 гг.) дело по расследованию убийства казначея Енисейского губернского правления коллежского секретаря Александра Мелиссова и произведенной им растрате казенных денежных сумм в размере 8085 руб. 88 1/4 коп. (ГАКК. Ф. 141. Оп. 1. Д. 659. Л. 1-297).

По делу проходило большое количество чиновников, разделенных в процессе рассмотрения советом Главного управления Восточной Сибири на три категории.

В «первую категорию обвиняемых» вошли лекарь Мажаров, красноярский полицмейстер Вахрушев, частный пристав Дурчеев, губернский стряпчий Павлинов, обвиняемые за неправильное установление факта самоубийства казначея Енисейского губернского правления А. Мелиссова, которое, как выяснилось позднее, оказалось убийством (утоплен в проруби реки Енисей 31.12 .1865 г., что привело к потере денежной суммы в размере 8085 руб. 88 1/4 коп.) (ГАКК. Ф. 141. ОП. 1. Д. 659. Л. 2 об.-8об.).

«Вторая категория обвиняемых» - это чиновники Енисейского губернского правления, а именно бывший председатель правления Гаупт, члены правления Малахов, Павлинов, а также заведующие казначейской частью Виноградов и Пашкевич. Они обвинялись в беспорядках и отступлениях от предписанных в законе правил для ведения счетоводства, упущениях по должности, слабом надзоре за подчиненными, нарушении в делах и порядке службы. Это подразумевало

$$
-1853-
$$


неправильное хранение в течение 1865 г. убитым А. Мелиссовым в собственной кладовой большой денежной суммы (в документе указана уже другая сумма в размере 8081 руб. 16 1/2 коп. - Авт.), приведшее к постепенной растрате и присвоению казенных средств в течение 1865 г. (ГАКК. Ф. 141. Оп. 1. Д. 659. Л. 9-13).

«Третья категория обвиняемых» включила в себя троих высокопоставленных чиновников, непосредственно связанных с убийством А. Мелиссова, произошедшим 31.12.1865 г.: управляющий экспедицией о ссыльных Енисейской губернии Грацианский (самовольное востребование из казначейства 8085 руб. 88 1/4 коп.); окружной казначей Костинский, а с 1873 г. уже губернский казначей (незаконная выдача данной денежной суммы казначею Мелиссову без надлежащих для того документов); сам убитый казначей губернского правления А. Мелиссов, обвиняемый в растрате потерянных 8085 руб. 88 1/4 коп. (ГАКК. Ф. 141. Оп. 1. Д. 659. Л. 13 об.-14).

Итогом данного громкого дела стало решение совета Главного управления Восточной Сибири освободить от ответственности «первую» и «вторую» категории обвиняемых, так как все они были освобождены от ответственности на основании ст. 410, 417, 429 Уложения о наказаниях, Виноградов умер от горячки в 1871 г. Совет постановил передать на рассмотрение в Енисейский губернский суд только чиновников из «третьей категории». Какое обвинение вынес Енисейский губернский суд такой информации в документах найдено не было (ГАКК. Ф. 141. Оп. 1. Д. 659. Л. 14-38об.).

Однако в формулярном списке губернского казначея Александра Вавиловича Костинского от 1873 г. указано: «...в штрафах, под судом и следствием не был» (ГАКК. Ф. 141. Оп. 1. Д. 659. Л. 42об.43). При этом бывшему управляющему экспедицией о ссыльных Енисейской губернии Петру Ивановичу Грацианскому (с 1875 г. - бухгалтеру Енисейской казенной палаты) по решению Правительствующего сената (Санкт Петербург) от 1882 г. был возвращен уплаченный из его жалованья штраф в размере 3000 руб., а судебные издержки приняты на счет казны (ГАКК. Ф. 141. Оп. 1. Д. 659. Л. 204).

Ответственность за растраченную денежную сумму понесла семья убитого казначея Енисейского губернского правления Александра Мелиссова: у вдовы Марфы Степановны Мелиссовой должен был быть конфискован дом и все движимое имущество, но так как она за годы расследования умерла, то дом остался за дочерью чиновника (ГАКК. Ф. 141. Оп. 1. Д. 659. Л. 66, 203-204).

\section{5. Заключение}

Официальная документация Енисейского общего губернского управления и Енисейского губернского суда 1860-1890-х гг. свидетельствует о признании центральной и местной государственной властью несовершенств в деятельности административных и судебных мест по выявлению преступлений со стороны местного чиновничества и определению в подобных случаях справедливого наказания. Конечно же, архивные документы не показывают истинного количества преступлений и проступков по государственной и общественной службе, совершенных на территории Енисейской губернии. Контент-анализ текстов формулярных списков (аттестатов), поименных списков осужденных чиновников, их характеристик и прочей внешней и внутренней распорядительной документации Енисейского общего губернского управления и Енисейского губернского суда показал портрет местного чиновника, совершившего незаконные действия по должности, а также процесс расследования подобных дел.

В официальных документах второй половины XIX в. признавалось, что введение нового судебного устройства могло бы дать вполне правильный ход делам в административном управлении. Обзоры Енисейской губернии за 1882, 1883 г., статистические материалы, подготовленные для всеподданнейшего отчета губернатора Енисейской губернии Министерству внутренних дел за 1893 г. приводят доводы о необходимости введения предлагаемых правительством преобразований «судебной части» в Сибири по реформе 1864 г. Властями и общественностью признавалось, что в связи с отдаленностью от политического центра огромная Сибирь и во второй половине XIX в. представляла определенный интерес для всякого рода преступных элементов, с одной стороны, стремившихся нажиться за счет государственной службы, с другой - столкнувшихся с возможностью совершить ранее не запланированные незаконные поступки, которые вряд ли могут быть раскрыты в связи со слабым контролем и надзором.

\section{Литература}

ГАКК - Государственный архив Красноярского края.

Дамешек, Дамешек, 2020 - Дамешек Л.М., Дамешек И.Л. Образы сибирских окраин империи как предмет зарубежной историографии XX-XXI вв. // Вестник Бурятского научного центра Сибирского отделения Российской академии наук. 2020. № 1 (37). С. 84-96.

Друзяка, Дударенок, 2018 - Друзяка А.В., Дударенок С.M. Институт нотариата на Дальнем Востоке России и в Маньчжурии (1879-1930-е гг.) // Ойкумена. Регионоведческие исследования. 2018. № 2 (45). C. $76-83$.

Карчаева, 2017 - Карчаева Т.Г. Енисейская губернская администрация: численность и состав (1822-1917 гг.). Красноярск: Изд-во СФУ, 2017. 252 с. 
Карчаева, 2019 - Карчаева Т.Г. Роль инородческих органов власти в имущественных отношениях хакасов в 1822-1913 гг. (исторический аспект) // Известия Иркутского государственного университета. Серия «История». 2019. Т. 29. С. 91-99.

Матханова, 2020 - Матханова Н.П. Хабаровские съезды сведущих людей и приамурский генерал-губернатор А.Н. Корф: поиски каналов коммуникации между властью и обществом в Имперской России // Гуманитарные науки в Сибири. 2020. Т. 27 (3). C. 65-71. DOI: 10.15372/HSS2O200311

Молнева, 2008 - Молнева М.С. Духовные ценности чиновничества в системе подбора кадров // Вестник Тамбовского университета. Серия «Гуманитарные науки». 2008. № 1. С. 321-325.

Писарькова, 2002 - Писарькова Л.Ф. К истории взяток в России (по материалам секретной канцелярии кн. Голицыных в первой половине XIX века // Отечественная история. 2002. № 5. С. 37-39.

Плех, 2019 - Плех О.А. Провинциальное чиновничество России в первой половине XIX в.: отечественная историография конца XX - начала XXI в. // Вопросы истории. 2019. № 11. С. 258-272.

Чуб, 2018 - Чуб H.B. Кадровая деятельность губернских органов России XIX в. в фондах федерального и региональных архивов // Вестник архивиста. 2018. № 2. С. 343-351.

Bloch, 2005 - Bloch A. Longing for the kollektiv: Gender, power, and residential schools in central Siberia // Cultural Anthropology. 2005. 20(4): 534-569.

Dyatlov, Dyatlova, 2020 - Dyatlov V.I., Dyatlova E.V. From the "Influx of the Yellow Race" to "Migrant Workers": Dynamics of the Languagesfor Describing Cross-Border Migrations in Russia // Journal of Siberian Federal University. Humanities and Social Sciences. 13(5): 623-638. DOI: 10.17516/1997-1370-0594

Gentes, 2003 - Gentes A. Licentious girls' and frontier domesticators: women and Siberian exile from the late 16th to the early 19th centuries // Sibirica. 2003. 3(1): 3-20.

Gryaznukhin et al., 2020 - Gryaznukhin A.G., Gryaznukhina T.V., Belgorodskaya L.V. Malyutina L.F. Charity as the Demonstration of Mentality of the Merchant Class and Entrepreneurs of Russia in the XIX century // Bylye Gody. 2020. 57(3): 1132-1141.

Karchaeva et al., 2018 - Karchaeva T.G., Garin E.N., Severyanov M.D. Who were the clerks in Siberia? Professional characteristics of Russian Empire local governmental officials from the 19th to the early 20ies century // Bylye Gody. 2018. 49 (3): 1287-1295.

Karchaeva et al., 2019 - Karchaeva T.G., Gergilev D.N., Luschaeva G.M. Hereditary Bureaucracy in East Siberian Government from XIX to the early XX century: Statistical Analysis on the Materials of the Yenisei Province // Bylye Gody. 2019. 51(1): 188-197.

Lyubichankovskiy, 2020 - Lyubichankovskiy S.V. Imperial Acculturation on Russian's Southeastern Frontier: An International Survey // RUDN Journal of Russian History. 2020. 19(3): 727-740.

Malyutina et al., 2019 - Malyutina L.F., Gergilev D.N., Gryaznukhin A.G., Zhabaeva L.B. (2019). Social Thought in Russia of Its Czarist-Era about the Place of Siberia in the State Structure of the Country // Bylye Gody. 2019. 54(4): 1429-1438.

\section{References}

Chub, 2018 - Chub, N.V. (2018). Kadrovaja dejatel'nost' gubernskih organov Rossii XIX v. v fondah federal'nogo i regional'nyh arhivov [Human resource management in the Russian gubernia institutions of the 19th century in the fonds of federal and regional archives]. Vestnik arhivista. 2: 343-351. [in Russian]

Dameshek, Dameshek, 2020 - Dameshek, L.M., Dameshek, I.L. (2020). Obrazy sibirskikh okrain imperii kak predmet zarubezhnoi istoriografii XX-XXI vv. [Images of the Siberian edge of the Empire as a subject of foreign historiography of the 20th - 21st centuries]. Vestnik Buryatskogo nauchnogo tsentra Sibirskogo otdeleniya Rossiiskoi akademii nauk. 37(1): 84-96. [in Russian]

Druzyaka, Dudarenok, 2018 - Druzyaka, A.V., Dudarenok, S.M. (2018). Institut notariata na Dal'nem Vostoke Rossii i v Man'chzhurii (1879-1930-e gg.) [Institute of the notariate in the Russian Far East and Manchuria (1879-1930s)]. Oikumena. Regionovedcheskie issledovaniya. 45(2): 76-83. [in Russian]

Dyatlov, Dyatlova, 2020 - Dyatlov, V.I., Dyatlova, E.V. (2020). From the "Influx of the Yellow Race" to "Migrant Workers": Dynamics of the Languagesfor Describing Cross-Border Migrations in Russia. Journal of Siberian Federal University. Humanities and Social Sciences. 13(5): 623-638. [in Russian]

GAKK - Gosudarstvennyi arkhiv Krasnoyarskogo kraya [State archive of the Krasnoyarsk Region].

Gryaznukhin et al., 2020 - Gryaznukhin, A.G., Gryaznukhina, T.V., Belgorodskaya, L.V. Malyutina, L.F. (2020). Charity as the Demonstration of Mentality of the Merchant Class and Entrepreneurs of Russia in the XIX century. Bylye Gody. 57(3): 1132-1141.

Karchaeva, 2017 - Karchaeva, T.G. (2017). Eniseiskaya gubernskaya administratsiya: chislennost' i sostav (1822-1917 gg.) [The Yenisei Provincial Administration: number: number and composition from 1822 to 1917]. Krasnoyarsk. [in Russian]

Karchaeva et al., 2018 - Karchaeva, T.G., Garin, E.N., Severyanov, M.D. (2018). Who were the clerks in Siberia? Professional characteristics of Russian Empire local governmental officials from the 19th to the early 2oies century. Bylye Gody. 49(3): 1287-1295. 
Karchaeva et al., 2019 - Karchaeva, T.G., Gergilev, D.N., Luschaeva, G.M. (2019). Hereditary Bureaucracy in East Siberian Government from XIX to the early XX century: Statistical Analysis on the Materials of the Yenisei Province. Bylye Gody. 51(1): 188-197.

Lyubichankovskiy, 2020 - Lyubichankovskiy, S.V. (2020). Imperial Acculturation on Russian's Southeastern Frontier: An International Survey. RUDN Journal of Russian History. 19(3): 727-740.

Malyutina et al., 2019 - Malyutina, L.F., Gergilev, D.N., Gryaznukhin, A.G., Zhabaeva, L.B. (2019). Social Thought in Russia of Its Czarist-Era about the Place of Siberia in the State Structure of the Country. Bylye Gody. 54(4): 1429-1438.

Mathanova, 2020 - Mathanova, N.P. (2020). Habarovskie s"ezdy "svedushchih lyudej" i priamurskij general-gubernator A.N. Korf: poiski kanalov kommunikacii mezhdu vlast'yu i obshchestvom v Imperskoj Rossii [Meetings of "Well-Informed People" in Khabarovsk and the Priamur Governor-General A.N. Korf: searching of communication channels between the authority and society in Imperial Russia]. Gumanitarnye nauki $v$ Sibiri. 27(3): 65-71. [in Russian]

Molneva, 2008 - Molneva, M.S. (2008). Dukhovnyye tsennosti chinovnichestva v sisteme pod kadrov [Spiritual values of bureaucracy in the system of staffing]. Vestnik Tambovskogo universiteta. Seriya: Gumanitarnyye nauki. 1. pp. 321-325. [in Russian]

Pisar'kova, 2002 - Pisar'kova, L.F. (2020). K istorii vzyatok v Rossii (po materialam sekretnoy kantselyarii kn. Golitsynykh v pervoy polovine XIX veka [On the history of bribes in Russia (based on materials from the secret office of Prince Golitsyn in the first half of the 19th century]. Otechestvennaya istoriya. 5: 37-39. [in Russian]

Plekh, 2019 - Plekh, O.A. (2019). Provintsial'noe chinovnichestvo Rossii v pervoi polovine XIX v.: otechestvennaya istoriografiya kontsa XX - nachala XXI v. [Provincial bureaucracy of Russia in the first half of the XIX century: domestic historiography of the end of the XX - early XXI century 2019]. Voprosy istorii 11: 258-272. [in Russian]

\section{Незаконные действия чиновников в Сибири второй половины XIX в. (контент-анализ документов Енисейского общего губернского управления и Енисейского губернского суда)}

Татьяна Геннадьевна Карчаева а , * Александр Григорьевич Грязнухин ${ }^{\text {, }}$

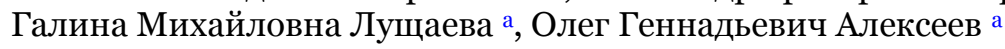

a Сибирский федеральный университет, Российская Федерация

Аннотация. В статье рассмотрены ранее неизвестные исторической науке факты должностных злоупотреблений местных государственных служащих в Сибири на примере Енисейской губернии второй половины XIX в. Источниковая база исследования представлена документами официального делопроизводства Енисейского губернского суда и Енисейского общего губернского управления 1860-1890-х гг., которые хранятся в одноименных фондах №141 и № 545 Государственного архива Красноярского края. Контент-анализ текста архивных документов (распорядительных, статистических и по личному составу) позволил выявить скрытую и систематизировать явную информацию, свидетельствующую о совершении местными чиновниками Енисейской губернии противозаконных действий по должности. Наиболее распространенными среди них были упущения от нерадения или медленности, присвоение или растрата казенного имущества и государственных доходов, превышение власти или беззаконное бездействие, слабый надзор за подчиненными, нарушение в делах и порядке службы. Наказание за данные преступления осуществлялось согласно нормам, описанным в пятом разделе «О преступлениях и проступках по службе государственной и общественной» Уложения о наказаниях уголовных и исправительных от 1866 г. Обзоры Енисейской губернии и официальная статистика свидетельствуют о небольшом количестве должностных преступлений - всего 1,4-2,5\% среди прочих по губернии. Приведенные в статье биографические данные конкретных чиновников окружного и губернского уровней власти рисуют среднестатистический портрет местного государственного служащего, привлеченного к ответственности. Однако на примере одного из уголовных дел 1860-х гг. (убийство казначея Енисейского губернского правления и похищение денежной суммы в размере 8085 руб. 88 1/4 коп.) доказано, что не все чиновники несли ответственность за совершенные преступления и упущения по службе.

Ключевые слова: чиновничество, государственные служащие, взяточничество, должностные преступления, злоупотребления, контент-анализ, губернский суд, общее губернское управление, Енисейская губерния, Сибирь, Российская империя.

\footnotetext{
${ }^{*}$ Корреспондирующий автор

Адреса электронной почты: tatyana-verkhoturova@yandex.ru (Т.Г. Карчаева) 